\title{
The Effect of Moringa Oleifera on Hemoglobin Level in Pregnancy
}

\author{
Joyce M. Laiskodat ${ }^{1}$, Rini Kundaryanti ${ }^{2}$, Shinta Novelia ${ }^{3 *}$ \\ 1,2,3Department of Midwifery, Faculty of Health Science Universitas Nasional, Indonesia; \\ shinta.novelia@civitas.unas.ac.id (Corresponding Author)
}

\begin{tabular}{l} 
Article Info: \\
\hline Submitted: \\
30-08-2021 \\
Revised: \\
01-10-2021 \\
Accepted: \\
11-10-2021
\end{tabular}

DOI:

https://doi.org/10.53713/nhs.v1i2.65

\section{(c) (i) (2)}

This work is licensed under CC BY-SA License.

\begin{abstract}
Anemia is a form of the body's compensation mechanism for decreasing hemoglobin levels. Anemia in pregnancy is a condition in which hemoglobin is below normal, which is below $11 \mathrm{~g} / \mathrm{dl}$. The most common cause of anemia in pregnancy is iron deficiency. Moringa leaves are one type of food that is rich in iron which can overcome anemia. The purpose of the study was to determine the effect of giving Moringa leaf soup on hemoglobin levels of pregnant women in the third trimester at the Oepoi Health Center, Kupang City in 2021. Quasy Experimental research design with a two group pre-test and post-test design. The study population was all pregnant women. The sampling technique is purposive sampling. The sample was 32 pregnant women with mild anemia. Statistical test using t-test. The location of this research was carried out at the Oepoi Health Center, Kupang City from July to August 2021. The research instrument was observation sheet and $\mathrm{Hb}$ measuring instrument. The results showed that the average hemoglobin of pregnant women before the intervention in the experimental group was $9.813 \mathrm{~g} / \mathrm{dl}$ with a standard deviation of 0.57 . The hemoglobin level of pregnant women after being given Moringa leaf soup in the experimental group was $11.494 \mathrm{~g} / \mathrm{dl}$ with a standard deviation of 1.24 . The average hemoglobin in pregnant women before intervention in the control group was $9.825 \mathrm{~g} / \mathrm{dl}$ with a standard deviation of 0.61 . The average hemoglobin in pregnant women after the intervention in the control group was $9.675 \mathrm{~g} / \mathrm{dl}$ with a standard deviation of 1.28 . Analysis using the ttest obtained a significance value of $0.000<0.05$. It can be concluded that there was a significant effect between giving Moringa leaf soup on hemoglobin levels in TM III pregnant women. It is hoped that in addition to consuming Fe tablets, it is also recommended to consume foods high in iron such as Moringa leaves to increase hemoglobin in pregnant women.
\end{abstract}

Keywords: Pregnancy; Moringa Oleifera; hemoglobin; anemia

\section{INTRODUCTION}

Pregnancy is an exciting time that every woman looks forward to. Every pregnancy is a life event of great significance. This is a time of great vigilance and change. Parents begin to see themselves, their partners, and the world differently. During the nine months it takes the baby to grow and develop so that one year later almost no parent's life remains the same as it was before pregnancy ("Maternal and Child Health", 2014). The results of Riskesdas 2018 show that $68.9 \%$ of pregnant women in Indonesia suffer from anemia, the results of Riskesdas in 2013 are $37.1 \%$, this shows that the incidence of anemia has increased over a five-year period, between 2013 and 2018 (Riskesdas, 2018). According to data from the NTT Provincial Health Office, in 2018, 46.2\% of pregnant women in East Nusa Tenggara suffered from anemia. Data from the Oepoi Health Center stated that the number of pregnant women in the work area from January to August 2021 was 272 people and the number of pregnant women with iron deficiency anemia was 131 people $(48.16 \%)$.

Anemia during pregnancy is one of the main causes of maternal and infant mortality. Pregnant women usually suffer from iron deficiency, so they provide only a small amount of iron to the fetus which is necessary for normal iron metabolism. Iron is required for the formation of hemoglobin and during pregnancy blood volume increases due to changes in the mother's body and blood supply to the baby. Iron deficiency can cause developmental disorders and barriers to the fetus and body and brain cells, fetal death in the womb, miscarriage, congenital defects, low birth weight (LBW) and anemia in infants (Maternal and Child Health, 2014).

Factors related to the incidence of anemia in pregnant women are parity, age, antenatal care (ANC) visits, and iron (Fe) intake (Purwandari, Lumy, \& Polak, 2017). One of the efforts to prevent and treat anemia in pregnant women is 
to increase knowledge, change attitudes, and be positive through education about nutritional needs during pregnancy, check pregnancy during pregnancy, give 90 tablets of iron, check $\mathrm{Hb}$ in semester I and III, and immediately check pregnancy if there are abnormal complaints, getting food according to the needs of pregnant women, increasing knowledge and behavior of pregnant women and their families, processing and providing food, and improving the quality of health and nutritional services (Solehati, Sari, Lukman, \& Kosasih, 2018).

Complementary therapy is chosen to support conventional medical treatment or as an alternative medicine outside of conventional medical treatment so that it is chosen as a way of healing disease (Ayuningtyas, 2019). Moringa leaves are one of the most widely grown foodstuffs in Indonesia. Moringa contains nutrients that are beneficial for health. According to Fuglie LJ in The Miracle Tree: The Multiple Attributes of Moringa quoted by Krisnadi (2015), states that fresh Moringa leaves contain 25 times more iron than spinach and iron, 1.77 times more is absorbed into the body. blood. Previous research conducted by Bora \& Asi (2017) showed that before and after consuming Moringa leaves had a significant effect on hemoglobin levels in pregnant women. Other studies also support this which shows that hemoglobin levels in both study groups increased significantly after the intervention (Nadimin, As'ad, \& Buchari, 2015). The increase in hemoglobin levels in the control group was twice that of the intervention group. Several other studies conducted by Fitriani (2020) and Rahmawati \& Daryanti (2017) showed the effect of increasing Hb levels before and after consumption of Moringa leaves in pregnant women with anemia. Based on the above background, the researchers are interested in researching "The Effect of Giving Moringa Leaf Soup on Hemoglobin Levels for Pregnant Women at the Oepoi Health Center, Kupang City in 2021".

\section{METHOD}

This study used a quasi-experimental design with a two group pre-test and post-test design to determine the effect of giving Moringa leaf soup on hemoglobin levels of pregnant women TM III at the Oepoi Health Center, Kupang City in 2021. The population in this study were all pregnant women who check her pregnancy at the Oepoi Health Center, Kupang City. The sampling technique used purposive sampling which was obtained by 32 pregnant women. This study was conducted by giving Moringa leaf soup $1 \mathrm{x} /$ day to the experimental group and the control group was not given intervention for 14 days. The examination includes $\mathrm{Hb}$ levels performed before and after the intervention. Data analysis used paired t-test statistical test and independent t-test test with a significant level of $p$-value $<0.05$.

\section{RESULT}

Tabel 1. Hemoglobin before and after intervention in both group

\begin{tabular}{lccc}
\hline Pregnant women & Mean & SD & $\mathrm{n}$ \\
\hline Experiment group & & & \\
$\quad$ Before & 9.813 & 0.57 & 16 \\
$\quad$ After & 11.494 & 1.24 & 16 \\
\hline Control group & & & \\
$\quad$ Before & 9.825 & 0.61 & 16 \\
After & 9.675 & 1.28 & 16 \\
\hline
\end{tabular}

Based on table 1. above, it is known that the average hemoglobin of pregnant women before the intervention in the experimental group was $9.813 \mathrm{~g} / \mathrm{dl}$ with a standard deviation of 0.57 . The hemoglobin level of pregnant women after being given Moringa leaf soup in the experimental group was $11.494 \mathrm{~g} / \mathrm{dl}$ with a standard deviation of 1.24 . It is known that the average hemoglobin in pregnant women before intervention in the control group was $9.825 \mathrm{~g} / \mathrm{dl}$ with a standard deviation of 0.61 . The average hemoglobin in pregnant women after the intervention in the control group was $9.675 \mathrm{~g} / \mathrm{dl}$ with a standard deviation of 1.28 .

Table 2. The differences of hemoglobin before and after intervention within both groups

\begin{tabular}{ccccc}
\hline $\mathrm{Hb}$ & Mean difference & Std. Deviation & $\mathrm{t}$ & Sig. (2-tailed) \\
\hline Before -after intervention group & -1.6813 & 0.9167 & -7.336 & 0.000 \\
\hline Before -after control group & 0.1500 & 1.3201 & 0.455 & 0.656 \\
\hline
\end{tabular}

Based on table 2. it can be seen that the mean value of the difference before and after the intervention of the experimental group is -1.6813 with a standard deviation of 0.9167 and a significant value of $0.000<0.05$ is obtained. This shows that there is an effect of giving Moringa leaf soup on hemoglobin levels of pregnant women. While the 
difference before and after the intervention was given to the control group, the mean value was 0.1500 with a standard deviation of 1.3201 and a significant value was $0.656>0.05$. This shows that there is no change in hemoglobin levels in that group.

Tabel 3. The differences of $\mathrm{Hb}$ between experiment and control group after intervention

\begin{tabular}{rccc}
\hline $\mathrm{Hb}$ & Mean difference & $\mathrm{t}$ & $\mathrm{p}$-value \\
\hline Between group & 1.82 & 4.060 & 0.000 \\
\hline
\end{tabular}

Based on table 3. the average difference in hemoglobin levels of pregnant women before and after being given Moringa leaf soup was $1.82 \mathrm{~g} / \mathrm{dl}$. The results of the comparison test of hemoglobin levels using paired t-test showed a significance value $(p)$ of 0.000 . It can be concluded that there were differences in $\mathrm{Hb}$ levels before and after the intervention between experimental group and the control group.

\section{DISCUSSION}

The results shows that the average hemoglobin of pregnant women before the intervention in the experimental group was $9.813 \mathrm{~g} / \mathrm{dl}$. The hemoglobin level of pregnant women after being given Moringa leaf soup in the experimental group was $11.494 \mathrm{~g} / \mathrm{dl}$. From these results, there was a significant difference in the provision of Moringa leaf soup on hemoglobin levels of pregnant women TM III. The results of research conducted by Triananinsi (2018) show that the consumption of Moringa leaf capsules in pregnant women is good for improving the status of $\mathrm{Hb}$ levels. This can be seen from the intervention group which 15 respondents who experienced anemia after consuming Moringa leaf capsules and Fe tablets for 30 days, the results were that there were 5 respondents $(33.3 \%)$ who experienced mild anemia and 10 respondents (66.7\%) who did not experience. Another study from Fitriani (2020) stated that of 15 pregnant women before consuming Moringa Oliefera, most of them experienced mild anemia, namely 10 respondents (66.7\%). Meanwhile, after consuming Moringa Oliefera, almost half of them did not experience anemia, 7 respondents (46.7\%). This means that there was an increase in hemoglobin levels to the incidence of anemia in pregnant women at Ponkesdes Mojorejo, Kedungadem District, Bojonegoro Regency in 2020.

Based on this study, in the experimental group of 16 pregnant women who were given the intervention, there were 6 pregnant women (37.5\%) who still experienced mild anemia despite an increase in hemoglobin. This can be caused because the mother's diet and rest will affect the absorption of iron in food. Pregnant women who are anemic will experience an increase in iron absorption due to the high need for iron so that there is an increase and after being given an intervention in the form of Moringa leaf soup because Moringa leaves contain iron and the content of vitamin $C$ and other vitamins can help iron absorption. An unbalanced diet will cause an imbalance of nutrients that enter the body and can lead to malnutrition or vice versa, an unbalanced consumption pattern also results in excess of certain nutrients and causes excess nutrition (Waryana, 2010). In pregnant women there is an increase in nutritional needs in each trimester. In order to achieve balanced nutrition, every pregnant woman is expected to consume at least one type of food sourced from carbohydrates, animal protein, vegetable protein, vegetables and fruit, besides that the amount of food is adjusted to the needs of pregnant women (Santoso, 2004). Short sleep duration or less will have a bad impact on the body. This is because the biological processes that take place during sleep will experience a disturbance, including the formation of impaired hemoglobin so that its levels become lower than normal values (Garno, Putri, \& Suhartik, 2020). Poor sleep quality will cause the sympathetic and parasympathetic nervous systems to be out of balance (Novelia, Sitanggang \& Yulianti, 2018). Thus increasing a person's hormones. The increase in these hormones can trigger non-smooth blood circulation so that it has a bad impact on pregnant women and can trigger anemia (Sarifansyah, Utami, \& Andinawati, 2018).

The average hemoglobin in pregnant women before intervention in the control group was $9.825 \mathrm{~g} / \mathrm{dl}$. The average hemoglobin in pregnant women after the intervention in the control group was $9.675 \mathrm{~g} / \mathrm{dl}$. Based on the results of the study in the control group, pregnant women who did not consume Moringa leaves for 14 days were 3 pregnant women with normal hemoglobin levels (18.75\%) and 13 pregnant women (81.25\%) who were still anemic. Research from Trianinsi (2018) shows that after and without consuming Moringa leaf capsules. Of the 15 respondents the most were in the mild anemia category 12 respondents $(80 \%)$ and the least were in the non-anemic category which was 3 respondents (20\%). Inadequate food intake causes insufficient available iron for hemoglobin synthesis due to iron deficiency in food, so the risk of anemia in pregnant women is high (Nurhidayati \& Hapsari, 2014). The occurrence of anemia in pregnant women is caused by an increased need for iron for the formation of red blood cells which is common in pregnancy and due to insufficient iron intake and inadequate absorption. Lack of consuming food sources of vitamin $\mathrm{C}$ 
and protein in addition to iron, protein also plays a role in the formation of red blood cells, protein must be in sufficient quantities so that the synthesis of hemoglobin goes well because protein has an important role in the absorption and transportation of iron otherwise. In addition, a healthy lifestyle for pregnant women is very important because the mother not only fulfills her own nutritional needs but also meets the needs of the baby in her womb, a low healthy lifestyle can affect the health of the mother and her baby, affecting the nutrients needed including iron which will effect on maternal $\mathrm{Hb}$ levels during pregnancy (Suheti, Indrayani \& Carolin, 2020; Novelia, Dewi, Melinasari, Widowati, \& Carolin, 2020).

Based on the results of the study, it can be seen in the experimental group and the control group that there were differences in $\mathrm{Hb}$ levels before and after the intervention. This indicates that the $\mathrm{Hb}$ level of pregnant women who were given the intervention was higher than that of pregnant women who were not given the intervention. Hemoglobin is a component of red blood cells that functions to distribute oxygen throughout the body, if $\mathrm{Hb}$ is reduced, body tissues lack oxygen. Oxygen is needed by the body to fuel metabolic processes. The function of hemoglobin is to act as an oxygencarrying unit of the blood that carries oxygen from the lungs to the cells, and carries $\mathrm{CO} 2$ back to the lungs (Arisman, 2010). Lack of hemoglobin ( $\mathrm{Hb}$ ) in the blood caused by lack of nutrients. Iron nutritional anemia is anemia caused by a lack of iron in the blood (Fathonah, 2016). Anemia will be found in the anamnesis in the form of complaints of fatigue, frequent dizziness, dizzy eyes, and complaints of frequent nausea and vomiting that are more severe in young pregnancy, the patient looks weak, lacks enthusiasm, the face, conjunctiva, lips, tongue, mucous membranes and nail bed are visible. pale. On palpation, splenomegaly and tachycardia may be found. On auscultation, a heart murmur can be heard (Priyanti, Irawati, \& Syalfina, 2020).

Based on the results of the analysis using the paired t-test and independent sample t-test, it can be seen that there was a difference in the increase in $\mathrm{Hb}$ levels in the experimental group, the average difference in hemoglobin levels of pregnant women before and after being given Moringa leaf soup was $1.82 \mathrm{~g} / \mathrm{dl}$. The results of the comparison test of hemoglobin levels showed a significance value (p) of 0.000 . Anemia of pregnant women has a considerable impact on themselves and the growth process of the fetus and the baby to be born. Anemia in pregnant women can increase the risk of various health problems for both the fetus and mother. The risks of health problems that can be experienced include babies born with low body weight (LBW), babies with congenital defects, mothers experiencing miscarriages, bleeding before and during delivery, even the risk of death of the mother and baby (Riskesdas, 2018). The need for iron in the first trimester is relatively less, which is around $0.8 \mathrm{mg}$ per day, but in the second and third trimesters it increases to $6.3 \mathrm{mg}$ per day (Tarwoto \& Wasnidar, 2013), while according to Saifudin (2006) the mother's needs during During pregnancy is $800 \mathrm{mg}$ of iron, of which $300 \mathrm{mg}$ for the fetus and the placenta and $500 \mathrm{mg}$ for the increase in maternal erythrocytes, thus the mother needs an additional about 2-3 mg of iron / day.Moringa leaves are a food that is easily available and contains a lot of iron, which is widely available in the Kupang City area. Consumption of Moringa leaves can increase the iron needed by the body for the formation of hemoglobin during pregnancy. The World Health Organization (WHO) calls the Moringa tree the Miracle Tree so that it is recommended for children and pregnant women for the fetus to consume Moringa leaves. Moringa leaves contain vitamin A, vitamin C, vitamin B, calcium, potassium, iron, and protein, in very high amounts which are easily digested and assimilated by the human body. Moringa leaves contain 4 times more betacarotene than carrots, 17 times more calcium than milk and 25 times more iron than spinach. In addition to preventing anemia, Moringa plants can act as antioxidants, help maintain glucose levels in the blood, accelerate the process of new cell and tissue growth, anticancer and antitumor, prevent bleeding, prevent coronary heart disease and as a source of fiber (Krisnadi, 2015).

Moringa leaves are used to fight malnutrition, especially for babies and pregnant women. The food consumed by pregnant women is related to the health of the unborn baby. This means that the step of supplementation with Moringa is considered very important in order to get the opportunity to get more vitamins, minerals, and other nutritional compounds. Moringa plant is an ingredient that is rich in multivitamins. So far no plant has matched the richness of Moringa plant minerals such as potassium, iron, calcium, and sulfur as well as B vitamins and all kinds of essential amino acids. Moringa plants are seen as a source of iron (31\% daily value requirement per 100 grams) (Winarno, 2018).

The results of this study are in line with research conducted on 30 pregnant women with samples before and after consuming Moringa leaf extract from the results of research that has been carried out in this study which the results of the analysis with the Wilcoxon test, it was found that the examination of the $\mathrm{Hb}$ levels of pregnant women before and after consuming Fe tablets with the consumption of Moringa leaf capsules showed the Asymp value. Sig. $0.000<0.05$ so it can be concluded that there was an effect before and after consuming Fe tablets with the consumption of Moringa leaf capsules (Triananinsi \& Marliana, 2019). Another study using Moringa leaf extract with the title The effect of Moringa leaf extract on increasing hemoglobin levels of pregnant women in the 2nd and 3rd trimesters at the Semanu I Health Center. The study was conducted on 32 respondents. The results based on the Paired t-test showed $p$ value $=0.000$ $<0.05$ which means that there was an effect of increasing $\mathrm{Hb}$ levels before and after consumption of Moringa leaves in pregnant women in the working area of the Semanu I Gunungkidul Health Centre (Rahmawati \& Daryanti, 2017). 
In line with research conducted by Fitriani (2020) it is known that before consuming Moringa Oliefera, most pregnant women experienced mild anemia. Meanwhile, after consuming Moringa Oliefera, almost some did not experience anemia. This means that the consumption of Moringa Oliefera regularly every day can increase the $\mathrm{Hb}$ level of pregnant women so that they can handle anemia that occurs in pregnant women. The results of another study conducted by Yulianti \& Alasiry (2016) using Moringa leaf extract to increase hemoglobin levels showed that there were differences in the hemoglobin levels of respondents in the group given Moringa leaf extract and those who were not given Moringa leaf extract. Then the results of research conducted by Bora \& Asi (2017) showed that $83.6 \%$ of pregnant women who frequently consumed Moringa leaves had normal hemoglobin levels $(>11 \mathrm{gr} \%)$. Hemoglobin in pregnant women can be increased by using pharmacological or non-pharmacological treatment. Local foods such as Moringa Oleifera, have health benefits that not only support pregnant women during pregnancy but also to prevent adverse pregnancy events.

\section{CONCLUSION}

Based on the results of research conducted at the Oepoi Health Center, Kupang City, the results of the analysis using paired sample t-test and independent sample t-test showed $\mathrm{Hb}$ levels of pregnant women TM III before and after consumption of Moringa leaf soup with $p$-value $0.000<0.05$. Thus, it can be concluded that there was a significant effect on giving Moringa leaf soup on $\mathrm{Hb}$ levels of pregnant women with TM III. With the results of research that Moringa leaves can increase hemoglobin levels, Moringa leaves can be used as an alternative natural food source to prevent anemia. In addition, there is a need for the role of health workers, especially midwives, in providing education to pregnant women to increase hemoglobin in addition to consuming Fe tablets, but also by using foods that contain lots of iron.

\section{ACKNOWLEDGEMENT}

The author would like to thank the National University for the support and partial funding that has been given so that this research can be carried out.

\section{REFERENCES}

Arisman. (2010). Gizi dalam daur kehidupan Buku ajar ilmu gizi (Edisi 2). Jakarta: EGC.

Atika, Z., Layli, A. N., \& Winiastri, D. (2021). Pengaruh Daun Kelor (Moringa Oleifera Lam) Terhadap Kadar Hb Ibu Hamil Di Pmb Zummatul Atika. Media Bina IImiah, 15(8), 4971-4978.

Ayuningtyas, Ika Fitria. (2019). Kebidanan Komplementer. Yogyakarta: Pustaka Baru Press.

Budijanto, D., Yudiyanto., Hardhana, B. Soenardi, T. (Ed). (2016). Data dan Informasi 2015 Profil Kesehatan Indonesia. Pusat Data dan Informasi, Kementerian Kesehatan Indonesia.

Fathonah, Siti. (2016). Gizi \& Kesehatan Untuk Ibu Hamil. Jakarta: Erlangga.

Fitriani, A. S. (2020). Pengaruh Konsumsi Moringa Oliefera Terhadap Kejadian Anemia Pada Ibu Hamil Di Ponkesdes Mojorejo Kecamatan Kedungadem Kabupaten Bojonegoro (Doctoral dissertation, Stikes Insan Cendekia Medika Jombang).

Garno, C., Putri, S. I., Suhartik. (2020). Hubungan Kualitas Tidur Dan Konsumsi Tablet. Jurnal Informasi Kesehatan Indonesia, 6(1), 19-25.

Riskesdas. (2018). Badan Penelitian Dan Pengembangan Kesehatan Kementerian Kesehatan RI.

Krisnadi, A. D. (2015). Kelor, Super Nutrisi. In Kelor Super Nutrisi. Pusat Informasi Dan Pengembangan Tanaman Kelor Indonesia, Kunduran Blora.

Mulati, E., Royati, O. F., Widyaningsih, Y. (Ed). (2014). Buku Ajar Kesehatan Ibu Dan Anak. Jakarta Selatan: Pusat Pendidikan Dan Pelatihan Tenaga Kesehatan. http://202.70.136.161:8107/100/2/02Buku-KIA-06-10-2015-small.pdf Accessed 05 April 2021

Nadimin, H. V., As'ad, S., \& Buchari, A. (2015). The extract of moringa leaf has an equivalent effect to iron folic acid in increasing hemoglobin levels of pregnant women: a randomized control study in the coastal area of Makassar. Int J Sci Basic Appl Res, 22(1), 287-94.

Nurhidayati, A., \& Hapsari, E. (2014). Hubungan Asupan Nutrisi Dengan Kadar Hb Pada Ibu hamil Di BPS Suratini Suwarno Surakarta. Jurnal Kesehatan Kusuma Husada. http://jurnal.ukh.ac.id/index.php/JK/article/view/47 Diakses pada tanggal 22 April 2021

Novelia, S., Dewi, A., Melinasari, S., Widowati, R., \& Carolin, B. T. (2020). Iron and Orange Extract on Hemoglobin among Anemic Pregnant Women in Nusa Tenggara Barat in 2018. Asian Community Health Nursing Research, 2(1), 8-12.

Novelia, S., Sitanggang, T. W., \& Yulianti, A. (2018). Effects of yoga relaxation on anxiety levels among pregnant women. Nurse Media Journal of Nursing, 8(2), 86-95.

Purwandari, A., Lumy, F., \& Polak, F. (2016). Faktor-faktor yang berhubungan dengan kejadian anemia. JIDAN (Jurnal IImiah Bidan), 4(1), 62-68. 
Profil Kesehatan Kota Kupang. (2018). Dinas Kesehatan Kota Kupang.

Priyanti, S., Irawati, S., \& Syalfina, A. D. (2020). Anemia Dalam Kehamilan. Mojokerto: Stikes Majapahit Mojokerto.

Rahmawati, M., \& Daryanti, M. S. (2017). Pengaruh Ekstrak Daun Kelor Terhadap Peningkatan Kadar Hemoglobinibu Hamil Trimester 2 Dan 3 Di Puskesmas Semanu I. https://core.ac.uk/display/147279699 Accessed 07 April 2021

Saifuddin. (2006). Buku Acuan Nasional Pelayanan Kesehatan Maternal dan Neonatal. Jakarta: YBP-SP.

Santoso, S, \& Anne Lies Ranti. (2004). Kesehatan Dan Gizi. Jakarta: PT.Rineka Cipta.

Sarifansyah, S., Utami, N. W., \& Andinawati, M. (2018). Hubungan Kualitas Tidur Degan Tekanan Darah Pada Ibu Hamil Trimester lii Di Puskesmas Dinoyo Malang. Nursing News: Jurnal Ilmiah Keperawatan, 3(1).

Solehati, T., Sari, C. W. M., Lukman, M., \& Kosasih, C. E. (2018). Pengaruh Pendidikan Kesehatan Terhadap Pengetahuan Deteksi Dini Dan Pencegahan Anemia Dalam Upaya Menurunkan AKI Pada Kader Posyandu. Jurnal Keperawatan Komprehensif (Comprehensive Nursing Journal), 4(1), 7-12.

Suheti, E., Indrayani, T., \& Carolin, B. T. (2020). Perbedaan pemberian jus daun kelor (moringa oleifera) dan kacang hijau (vigna radiata) terhadap ibu hamil anemia. Jurnal akademi keperawatan husada karya jaya, 6(2).

Tarwoto \& Wasnidar. (2007). Buku Saku Anemia pada Ibu Hamil : Konsep dan Penatalaksanaannya (Cetak 1). Jakarta: Trans Info Media.

Triananinsi, N. (2019). Pengaruh Konsumsi Kapsul Daun Kelor Terhadap Kadar Hb lbu Hamil Di Wilayah Kerja Puskesmas Biru Kab. Bone Tahun 2018. Jurnal Antara Kebidanan, 2(3), 104-114.

Try Restiningtyas David Bora, P., \& Asi, M. (2017). Hubungan Pola Konsumsi Daun Kelor Dengan Kadar Hemoglobin Ibu Hamil Di Wilayah Kerja Puskesmas Kandai Kota Kendari Provinsi Sulawesi Tenggara Tahun 2017 (Doctoral Dissertation, Poltekkes Kemenkes Kendari).

Waryana. (2010). Gizi Reproduksi. Yogyakarta: Pustaka Rihana.

Winarno, F. G. (2018). Tanaman Kelor (Moringa Oleifera) Nilai Gizi, Manfaat, Dan Potensi Usaha. Jakarta: PT. Gramedia Pustaka Utama.

Yulianti, H., Hadju, V., \& Alasiry, E. (2016). Pengaruh ekstrak daun kelor terhadap peningkatan kadar hemoglobin pada remaja putri di SMU Muhammadiyah Kupang. JST Kesehatan, 6(3), 399-404. 